\title{
IRRIGATED AGRICULTURE AND POVERTY REDUCTION IN KASSENA NANKANA DISTRICT IN THE UPPER-EAST REGION, GHANA
}

\author{
R. D. Dinye \\ Centre for Settlements Studies, College of Architecture and Planning, \\ KNUST, Kumasi
}

\begin{abstract}
In northern Ghana, where the climatic conditions do not allow for an all-year-around rain-fed agriculture, irrigation is a necessary complement to enhance livelihoods security and poverty reduction. The knowledge gap regarding the contribution of existing irrigation facilities to poverty reduction occasioned the case study of the Tono irrigation scheme located in the Kassena Nankana District in the Upper East Region of Ghana. A treatment and control experimental approach was adopted in the investigation. The treatment group comprised a sample of 93 out of the 1,328 Tono irrigation tomato farmers and the control group sampled 86 out of 614 irrigation tomato farmers operating outside the Tono irrigation scheme. The Tono irrigated scheme has, to a considerable extent, created a platform for employment and high agricultural output. However, the high agricultural output has not been translated into increased income and improved livelihoods for the farmers and as such limits the impact of the efforts exerted towards poverty reduction amongst the farmers in the area. The challenges that led to this outcome include high cost of hiring farm machinery, inadequate access to credit, poor water supply for irrigation, ineffective technical assistance, lack of entrepreneurial skills, inability to store perishable products and inadequate ready market to translate the outputs into improved incomes for the farmers. Actors in the irrigated agriculture industry should pay equal attention to both the production and marketing aspects of their enterprises. The actors should ensure that the necessary inputs are available and affordable to farmers.
\end{abstract}

Keywords: Agriculture, Ghana Irrigation, Poverty, Tono Irrigation Scheme, Ghana

\section{INTRODUCTION}

The Republic of Ghana, with a total area of 238,540 square kilometers, is situated on the west coast of Africa. The country, which is subdivided into 10 political administrative regions, is characterized by a north-south divide in terms of living conditions and life opportunities. The Upper West, Upper East and Northern Regions constitute what is referred to as Northern Ghana or simply, the North. The rest of the country comprising the Brong Ahafo, Ashanti, Western, Eastern, Central, Volta and Greater 
Accra Regions are designated as Southern Ghana or the South. Generally, the North is well noted as poverty stricken and a hunger spot in the country (GLSS, 2000). The high incidence of poverty in the North is attributed to heavy reliance on rain-fed agriculture, subsistence farming and exclusion from trade (Aryeetey and Mckay, 2004; ODI and CEPA, 2005).

It is only in few areas in Ghana that the climate is favourable for non-irrigated agriculture. For much of the country, and especially the north, a single season of rainfall gives rise to one growing season. Even in the south-western forest zone which has the highest rainfall, irrigation is essential for short season crops during the dry period. The unreliability of rainfall has implications for the incidence and dimensions of poverty. The most recently sourced data indicated that overall poverty in Ghana stood at $28.5 \%$ in the year 2006 considering the lower poverty line of an average daily income level of US $\$ 1.25$ and $53.6 \%$ on the basis of the upper poverty level of a daily income of US $\$ 2.00$ respectively (UNDP, 2008). One of the innate measures to reduce poverty is to enhance agricultural production especially in the rural communities. The United Nations Development Programme (UNDP) indicated that rural poverty rates in sub-Saharan Africa remain as high as $51 \%$ (IFAD 2001; UNDP, 2008). Increasing agricultural productivity is paramount to poverty reduction. Ghana is not self-sufficient in food production, making adequate food availability in all year round a difficulty for some people. Rain-fed agriculture is predominant and average farm size of 1.2 hectares is small. Smallholder farms, accounting for about $80 \%$ of total agricultural production, dominate the sector.

\section{Irrigated Agriculture}

Investment in irrigation infrastructure constitutes an important poverty alleviation strategy since it would boost agricultural productivity by reducing the risks associated with the rainfall unreliability in Sub-Saharan African coun-

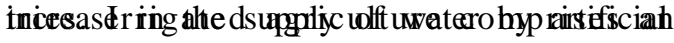
means through the use of water control technology allowing for the drainage to dispose of excess water (FAO, 1999). The government of Ghana has used irrigation development as a strategy towards increasing agricultural productivity and reducing rural poverty in the north (ICOUR, 2007). The positive impact of irrigation includes improved access to food and hence better nutrition to some extent, though this effect is limited since irrigation contributes less than $3 \%$ of the country's food production.

The strategic focus of the irrigation sub-sector is to increase agricultural production through the development of water resources for irrigation. The measures to be employed towards the achievement of this policy framework include the efforts of Government to:

- support the establishment of microirrigation and valley bottom irrigation schemes among rural areas;

- empower local authorities to assume a central role in supporting community operation and maintenance of small-scale irrigation and other food production facilities;

- promote partnerships between the public and private sector in the establishment and operation of commercial irrigation infrastructure;

- encourage the efficient use of fertilizers and other inputs mindful of reducing water pollution as well as high-yielding crop species;

- promote and encourage water use efficiency techniques in agriculture and reduce transmission losses of irrigation water in irrigation schemes;

- develop a pricing system and a mechanism for the delivery of irrigation water that is affordable for farmers and also ensure cost recovery on investments made in infrastructure; and

- utilise hydrological data and information, land cover and land use, soils and socioeconomic elements for the planning, des- 
sign and development of irrigated agriculture.

When irrigation development in Ghana started in the 1960s, big irrigation schemes were trendy. The current irrigation policy in Ghana is skewing towards the development of smallscale irrigation schemes which District Assemblies can easily construct and maintain. The ministries connected with irrigation in Ghana are the Ministry of Food and Agriculture and the Ministry of Environment, Science, and Technology. In the Ministry of Food and Agriculture (MoFA), the Ghana Irrigation Development Authority (GIDA) is the main institution in charge of irrigation. The development of the Tono Irrigation scheme has been funded by the government. According to the International Water Management Institute (IWMI, 2007), there exist both direct and indirect benefits of irrigated agriculture with respect to poverty alleviation. Direct linkages operate through localized and household-level effects, and the indirect linkages operate through regional, national, and economy-wide growth effects. All year cropping increases production and stabilizes the employment opportunities of the farmers thus ensuring enhanced wages for farm households. Ultimately, these benefits will improve the standards of youth employment and reduce the levels of rural poverty.

\section{Irrigation in Ghana}

Government-developed irrigation schemes in the entire country are 22 in number (IFPRI, 2011). The 22 public irrigation districts are managed by Ghana GIDA (Fig.1). Auspiciously, the Tono Irrigation Scheme (Fig. 2) has the largest agriculture dam in West Africa. As at the time of completion of the Tono irrigation scheme in 1985, it was Ghana's largest irrigation scheme. It comprised a $5 \mathrm{~km}$ long dam, which created an artificial lake with a surface area of 1,860 hectares. It had a water storage capacity of 93 million $\mathrm{m}^{3}$ of water, 37 million $\mathrm{m}^{3}$ of which could be used for irrigation. The irrigation infrastructure development and the preparation of farm plots involved clearing, leveling, and bonding. The original layout targeted the development of more than 2,400 hectares of irrigable land. The irrigation plots were served by two main canals (left bank and right bank) with an overall length of 42 kilometres and a network of laterals and sub-laterals of a further 210 kilometres, a total of 120 kilometres of roads were created to provide access (Asare, 2002; Salifu, 1998).

However, the district records a prevailing poverty incidence of $88 \%$ (NDPC, 2009). Food security is as low as $1.3 \%$ with $15 \%$ of the population with limited access to sufficient and nutritious food as compared to a national average of 5\%. Many of the farmers rely heavily on rain-fed agriculture (WFP, 2009).

The purpose of this paper is not to only unveil some of the underlying causes of the prevalence of poverty but also to evaluate the tacit efforts made to improve irrigated agriculture in the district. In an attempt to expose the reasons for the failed attempts, two objectives were pursued:

(i) to assess the operation and management of the Tono public irrigation scheme,

(ii) to ascertain the challenges and prospects of irrigated agriculture for sustainable rural poverty reduction policies. The analysis, therefore, basically considers the specific conditions of the Kassena Nankana District in the Upper-West Region of Ghana in particular from which relevant inferences can be drawn for similar areas.

\section{MATERIALS AND METHODS}

The study was conducted in the KassenaNankana District in the Upper East Region of Ghana. The drought in Northern Ghana is the major problem that the irrigation strategy intends to address. The Kassena-Nankana District has as much as $68.7 \%$ of its economically active population employed in agricultural activities (GoG, 2010). Although the district has the second largest irrigation scheme in the 


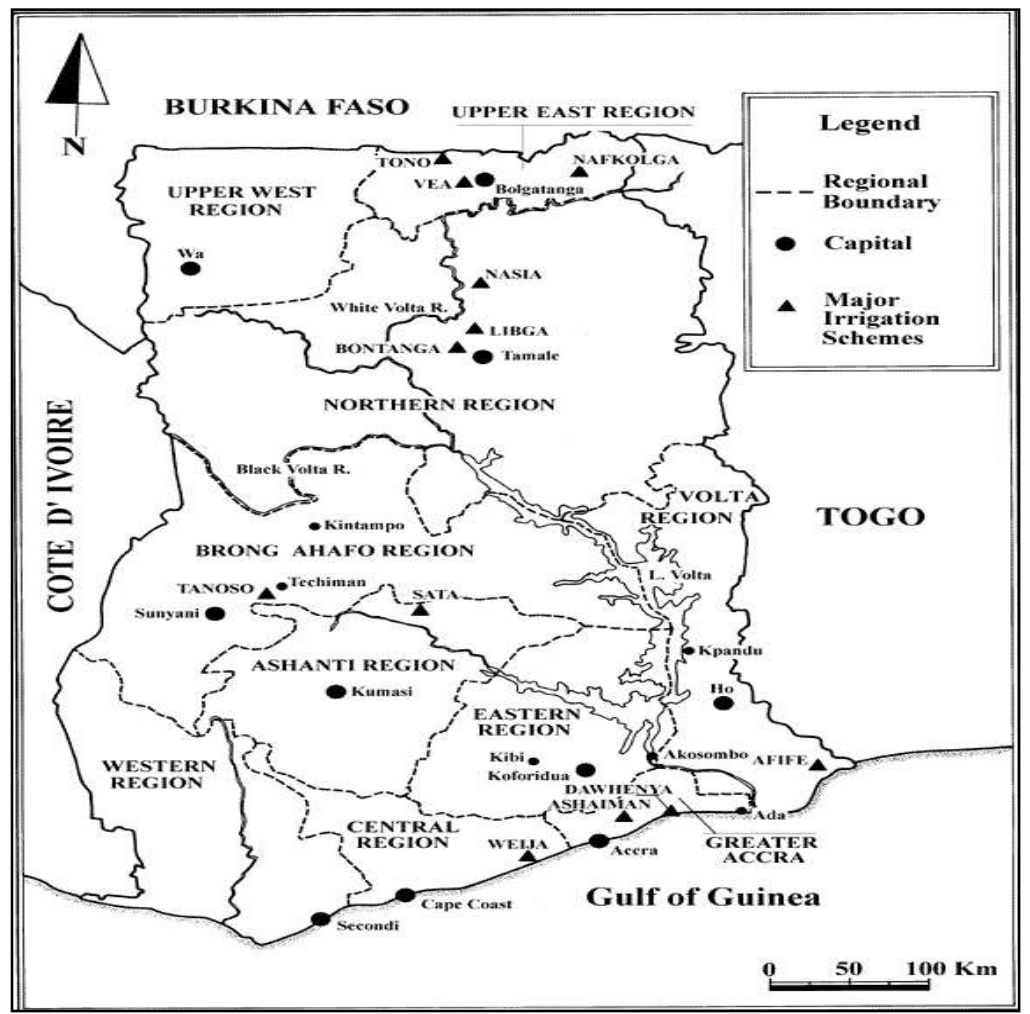

Fig 1: Major irrigation schemes in Ghana: Tono in Upper East Region

Source: Donkoh et al (2013)

country and has the largest agriculture dam (Tono Dam) in West Africa, it records a prevailing poverty incidence of $88 \%$ (NDPC, 2009). Food security is as low as $1.3 \%$ with 15 $\%$ of the population with limited access to sufficient and nutritious food as compared to a national average of $5 \%$. The paper focuses on the Kassena Nankana District (KND) of the Upper East Region, which is one of the poorest and drought prone regions of the country and where irrigation is practiced. It seeks to find out the extent to which irrigation could constitute an effective instrument for poverty reduction.
The target group or units of investigation comprise the farmers engaged in crop production in the Tono irrigation project. A sample of 93 project farmers were selected from the sampling frame of 1380 farmers on the project at a confidence level of $90 \%$ employing the statistical formula as follows:

The statistical sampling method adopted to select samples is illustrated as follows:

$$
\mathrm{n}=\mathrm{N} / 1+\mathrm{N}(\alpha)^{2}
$$

Where $N=$ sample frame, $n=$ sample size, $\alpha=$ error margin. 


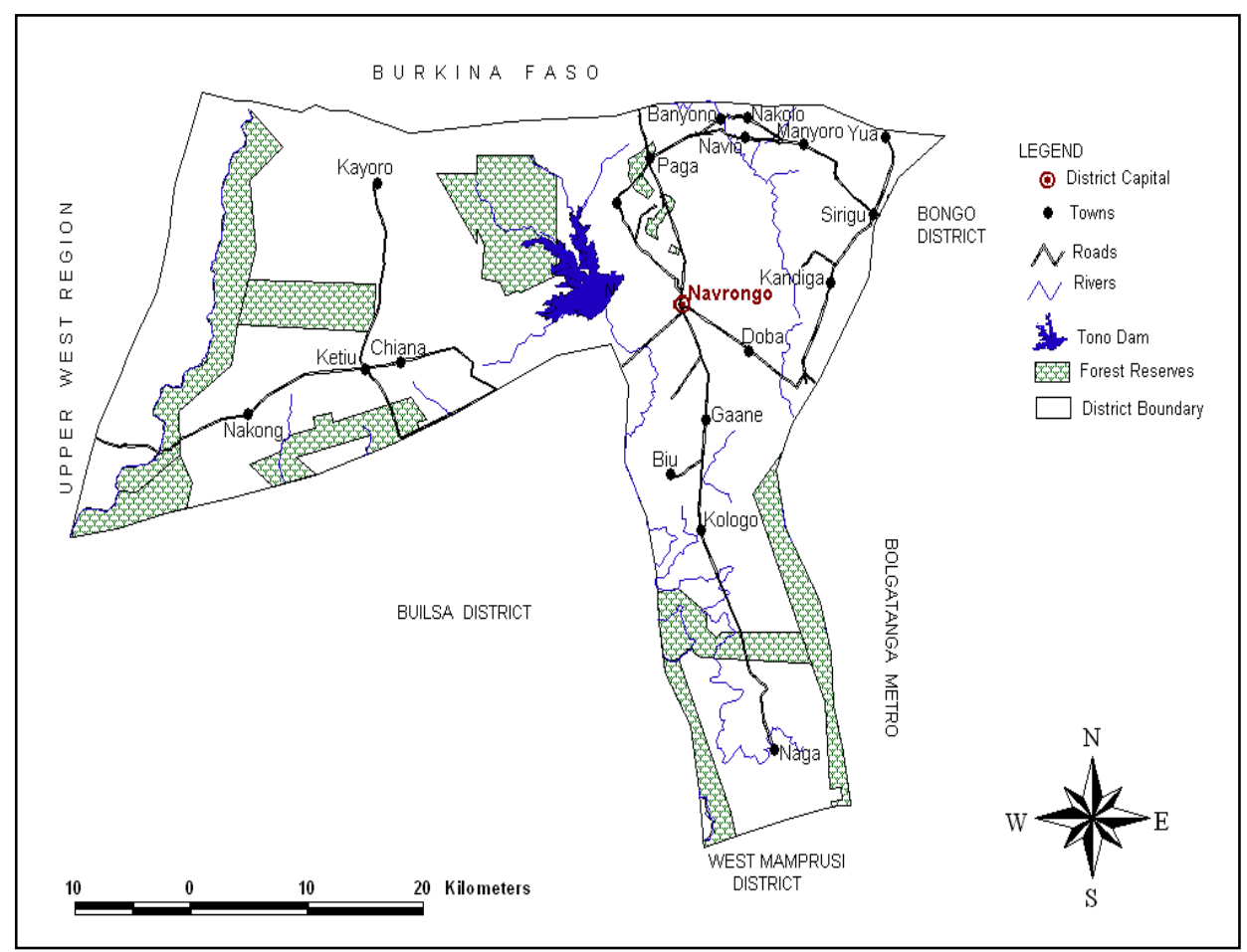

Fig. 2: Map of the Kassena Nankana District: the Study Area

Source: Kassena-Nankana District Assembly, 2010

In a similar manner, a sample of 86 farmers out of the other irrigation farmers (control group) across the district but outside the Tono irrigation scheme was obtained from a sampling frame of 623 counts during the reconnaissance survey which was assisted by the Ministry of Food and Agriculture in the District. Simple random and snowball sampling techniques were adopted in the selection of units for investigation. Simple random sampling requires that each member of the population has an equal chance of being selected as a subject. This was possible with the Tono irrigation farmers because each farmer has a designated plot. Each subject was selected independently of the other members of the population. Each plot was assigned a unique number. These numbers were placed in a bowl and mixed thoroughly. The investigators then picked the numbered tags from the bowl until the sample size of 93 farmers was obtained. The farmers whose plots were picked by the researcher constituted the subjects for the experimental group for the study.

Snowballing, a non-probability sampling technique, was purposively used to identify and interview the control group. The distribution of the control group was not in any identifiable patterned order. By the snowballing technique, the investigators began with one case and based on information about the interrelationships from that case and subsequent ones, other cases were identified and the process was repeated. After the sample selection, the investigators 


\section{Dinye}

went round to interview the first identifiable irrigators outside the Tono irrigation scheme who, then after, referred to other irrigators of their kind in the district for contact and interview. The investigators were mindful in ensuring a fair spread out of the 86 interviewees across the district.

Information was also collected from the management of the Irrigation Company of the Upper Region (ICOUR), the District office of the Ministry of Food and Agriculture (MoFA), the District Agriculture Extension Office, and food crop sellers in the Navrongo Central Market and used for analysis. The instruments employed in the data collection included questionnaires, focus group discussion, personal interviews and the researchers' personal observations.

\section{RESULTS AND DISCUSSION}

In this section of the paper, the nature and operation of the Tono Irrigation scheme, its management, benefits and constraining elements as well as the intervention measures put in place to ensure its sustainability were analysed.

Land Acquisition: Acquiring arable land for cultivation under the Tono irrigation scheme is not much of a difficulty due to the system adopted. While $18.4 \%$ of the 2,334 hectares of the irrigable land is managed and fairly leased to farmers by ICOUR, the remaining $81.6 \%$ of the land is put under the care of the Village Committee made up of selected beneficiary farmers. Similarly, farmers of the control group have no difficulty in acquiring land for cultivation. As much as $72.1 \%$ of them cultivated on land they had inherited.

Farming methods: Only $25.8 \%$ of the experimental group adopted capital intensive approaches involving the use of tractors to cultivate while intermittently engaging the services of hired labour. The situation of the control group respondents fell short of that. While $3.5 \%$ of respondents adopted the capital intensive approach, $12.8 \%$ adopted both methods when necessary. The rest relied on muscle power and attendant techniques. The low patronage of the capital intensive system by both groups is attributed to the high cost of renting farm machinery coupled with the low access to credit facilities.

Crop financing: A large proportion (92.5\%) of the project farmers do not have access to credit facilities and depend on family and friends to finance crop production. Likewise, $89.5 \%$ of the farmers in the control group do not have easy access to credit to finance crop production. The farmers' inability to access finance is attributable to lack of collateral security and the reluctance of some farmers to take loans. Consequent upon the rather considered high interest rate and the time allotted for payment, they are hardly in position to determine their ability to pay back on schedule. There is great uncertainty surrounding the prospects of success. There is therefore inertia on the part of both borrowers and lenders to venture. Farmers must have collateral security for the loan and must also be in groups. Most farmers find it difficult to meet these conditions. Besides, the interest rates according to the farmers are very high (25 $-35 \%)$ making repayment rather difficult. The Tono irrigation scheme farmers, in principle, apply fertilizer and herbicides and ICOUR insists on their use and plays an active role in securing these inputs for them. These are sold on credit to them to be paid back in cash or in kind (with the produce after harvesting. However, this is becoming a problem. According to ICOUR report (2007), credit recovery rates have declined from $94 \%$ in 2001 to $59 \%$ in 2006 due to high input cost and low price for farm produce. The implication of lack of access to credits coupled with cost and low price for farm produce. The implication of lack of access to credits coupled with and do mostly on credit. Availability of credit and finance often unlock a constraint on the ability of households to hire labour and buy inputs (Booth and Mosley, 2003).

Limited access to credit compels the farmers to buy inputs on credit. To pay back, they are also 
compelled to sell their produce immediately after harvest at the risk of low price making farming enterprise less lucrative. As such, some of the farmers complained that they sometimes cannot recoup their investment. The lack of access to credit and finance compel farmers to produce without applying the needed inputs for high productivity and market surplus. The farmers are, therefore, unable to produce beyond the subsistence level.

Technical assistance: Irrigation farmers of both groups received technical assistance from the Agricultural Extension Services Division of the Ministry of Food and Agriculture in the form of extension know-how, supply of subsidized fertilizers, jumping machines and farm implements, provision of improved tomato and rice seedlings. Many $(61.7 \%)$ of the project farmers had access to the technical services rendered by these officers as compared to $41.9 \%$ of the farmers in the control group who indicated that they received assistance. Management of ICOUR assists project farmers in terms of material inputs, technology transfer and credit. Under its Credit and Marketing Agreement Scheme, the company provides farmers with fertilizer, rice seedlings and/or land preparation services and other farm inputs for which farmers are to repay after harvesting either in cash or kind.

Irrigation water supply: As crucial as water supply is to irrigation farmers and $57 \%$ of the project farmers interviewed responded in the affirmative that the water supply to their farmlands is regular and adequate. Some of the subcanals that distributed the water to the various farmlands were broken causing the water to overflow and flood the farm lands. The water situation with the control group farmers is somewhat different. The sources of irrigation water are hand-dug wells, rivers and dams. Farmers do not pay for any form of charges but dig up wells through organized communal efforts. As much as $76 \%$ of the control group as against $43 \%$ of the experimented (project) group farmers experienced difficulties ace- ssing water for irrigation.

Crop storage: Twenty percent $(20 \%)$ of the farmers were engaged in vegetable production which is easily perishable. As much as $46.2 \%$ of the project farmers captured in the study do not have any form of storage facilities for their produce. The $53.8 \%$ of farmers who stored their produce in silos, rooms or barns cultivated rice, maize, onions and other non-perishable crops. The control group had a more serious situation with storage since $83.2 \%$ of them were vegetable crop farmers. The farmers' inability to store their produce compelled them to sell the produce at very low prices to avoid complete loss.

Marketing of farm produce: Access to ready market for farm produce has been a challenge to farmers under the Tono irrigation scheme as well as for the farmers in the control group. About half (i.e. 52.7\%) of project farmers did not have ready market for their farm produce. A larger proportion (i.e. 67.0\%) of the respondents in the control group did not have ready market for their farm produce. An in-depth interview with respondents and management of ICOUR revealed some of the reasons accounting for the market failure. Abayale Juliana, a vegetable seller from the Navrongo central market had this to say:

“...customers prefer farm produce from Burkina Faso and farm produce from the control group to produce from Tono because, the Burkina farmers use organic manure for production giving the crops quality taste...."

Mr. Sebastian Bagna, the Project Manager of ICOUR confirmed that:

"Tomato vendors from Kumasi prefer produce from Burkina Faso to Tono because, our farmers use too much chemicals to ripen the vegetables earlier than they should, causing them to rot easily".

This confirms the findings of earlier investiga- 


\section{Dinye}

tions (IFPRI, 2010; IFPRI, 2011) that the fruits and vegetables from the Sahel countries which include Burkina Faso, Mali and Niger are of higher quality than the Tono irrigation scheme in Ghana. The farmers at the Tono irrigation scheme use chemicals to force-ripe the produce thereby reducing the natural quality.

The manner in which Tono irrigation farmers sell their produce may as well be a cause of their failure and vulnerability. Whilst $61.3 \%$ choose to market their farm produce at the market centre, others choose to sell their produce by the road side $(21.5 \%)$ at the mercy of the hot sun and passers-by. The farmers do not have a target ready market to sell their produce most of which are easily perishable. Prices are, therefore, dictated by customers because they have no means of storing these perishable produce.

\section{Management of Tono Irrigation Project}

Management of the project is not entirely executed by ICOUR. Farmers do participate in the operation and maintenance of the project as well. Of the 93 farmers interviewed, $51.6 \%$ indicated their contribution to the operation and maintenance of the project in various ways. These include their activities as members of village development committees $(10.8 \%)$, decision making through public fora $(20.4 \%)$ and provision of labour services during sub-canal cleaning and maintenance $(21.5 \%)$. The rest of the $47.3 \%$ did not indicate any participation. The high none-response $(47.3 \%)$ with regard to the participation of farmers in the programme must be understood within the context of the design and execution of the irrigation scheme. The Tono irrigation scheme was constructed during the period spanning from 1975 to 1985 . Decision making as to the planning and implementation of such projects was centralized. It was the matter of the Government of Ghana in partnership with the Canadian and British governments. The farmers in the district, whom the project was meant to benefit, had no role to play in the planning, implementation, operation and management of the scheme. On completion, the farmers were given terms under which they could use the infrastructure facilities of the scheme.

\section{Impact of Tono Irrigation Project \\ Income of farmers}

For the purpose of this study the farmers were classified into three groups on the basis of their seasonal income from their irrigation farming. They comprised low income of less than Gh $\phi$ 500; medium income of between Gh $₫ 500$ and1000; and Ghф1001 and above. For the overall sample of the 189 farmers only $3.5 \%$ of the farmers were within the high income group. The low and medium income categories in each case constituted $45.0 \%$ and $51.5 \%$ respectively. The pattern of the distribution of the income level sub-categories of the experiment and control groups follow different trends. In the experimental group, most of the farmers (i.e. $59.1 \%$ ) were in the medium income category. Only a paltry $6.5 \%$ were in the high income with the rest (i.e. $34.4 \%$ ) within the low income earners. In the control group no high income earners were recorded. The majority (i.e. $55.8 \%$ ) were in the low income category with the rest (i.e. $44.2 \%$ ) in the medium income category.

With the institutional and technical assistance given out to project farmers by the management of ICOUR and MoFA coupled with the availability of irrigation water, it is expected that an appreciable difference in income is reaped by project farmers when compared to the control group. However, the situation suggest otherwise. The indication is that the direct impact of the project on the income levels of project farmers is far from that anticipated. As shown in Table 1, it has a rather modest effect on the livelihood of the project farmers and the dependents and this is caused by the poor marketing strategy adopted.

\section{Household Economic Situation}

The farmers' perception of their current household economic situation was assessed to evaluate the project impact on their household living conditions. Well over half $(55.9 \%)$ of the sam- 
Table 1: Incomes levels of irrigation farmers

\begin{tabular}{lcccccc}
\hline \multicolumn{1}{c}{ Income Level } & \multicolumn{2}{c}{ Experiment Group } & \multicolumn{2}{c}{ Control Group } & \multicolumn{2}{c}{ Total sample } \\
& No. & $\mathbf{\%}$ & No. & $\mathbf{\%}$ & No & \% \\
\hline Low $(<$ Gh $\varnothing 500)$ & 32 & 34.4 & 48 & 55.8 & 80 & 45.0 \\
Medium $($ Gh $\varnothing 501-1000)$ & 55 & 59.1 & 38 & 44.2 & 93 & 51.5 \\
High $($ Gh $\varnothing 1000+)$ & 6 & 6.5 & 0.0 & 0.0 & 6 & 3.5 \\
Total & $\mathbf{9 3}$ & $\mathbf{1 0 0}$ & $\mathbf{8 6}$ & $\mathbf{1 0 0}$ & $\mathbf{1 7 9}$ & $\mathbf{1 0 0}$ \\
\hline
\end{tabular}

Source: Authors' Fieldwork

pled project farmers were dissatisfied with their household economic situation and declared their state as desperate. The situation within the control group was worse, since a higher proportion of $61.8 \%$ were dissatisfied with the state of their household financial condition. Under the project, the situation of some project farmers was precarious and beyond description. A medical officer, Attiru Gilbert, a pioneer beneficiary of the Tono irrigation project put it as follows:

"Today, Tono is no more beneficial as it was when we started farming in the early 1980's. One could buy a motor bike with income from one season, some even built houses because of Tono, but today, we are engaged in the farming because we do not have anything else to do..."

The validity of this assertion is traceable to the Structural Adjustment programme which Ghana launched in 1983. This programme was meant to reverse the decline of the country's economy which took place for almost a decade. The anti-dote was "getting the prices right" which is a market mechanism of allowing the forces of demand and supply. State intervention which hitherto included subsidies and taxexemptions were to be at least minimized but at best abolished. Prior to the Structural Adjust- ment Programme, the government in its bit to assist agricultural production subsidized such inputs such as fertilizer, pesticides, weedicides and insecticides. The pioneer farmers of Tono irrigation scheme benefited from the subsidised agricultural inputs regime. With the removal of the subsidies their fortunes started to dwindle since they started paying for what they did not do earlier on.

An interface between the investigator and respondents in focus group discussions was held to establish if respondents observed any improvement in their household financial conditions over the past five years. It was also to establish whether such improvements could be attributed to the irrigated farming in the district. The focus group participants indicated that they had experienced improvements over the last five years but not as much as they anticipated.

\section{Food Security}

The essence of irrigated agriculture is to complement rain-fed agriculture to ensure food security in Ghana. One major finding was the limited impact of the Tono irrigation project on food security. As the hub of agricultural activities, it could readily be presumed that with abundant food supply, prices would be lower in the district as compared to other non- 


\section{Dinye}

producing areas. However, the situation is not so as food prices are low during harvest and highly inflated a few months later. Due to the absence of storage facilities for the large volumes of perishable produce, farmers are compelled to sell out their produce at low prices to avoid major loss. Subsequently, food becomes scarce and expensive in the district shortly after harvesting since the produce cannot be stored for future consumption. The high cost makes access to food difficult for the poor. As confirmed by the 2003 Core Welfare Indicators Questionnaire (CWIQ) survey, $57.9 \%$ of the households in the district had difficulty in meeting their food needs as compared to $12.8 \%$ at the national level (GSS, 2008).

\section{Out-Migration}

As one of the largest public irrigation facilities in West African (FAO, 2007), the Tono irrigation scheme engages an average of 1,380 young people seasonally (May-October) in agriculture. This has reduced the number of youth who migrate to the urban areas in southern Ghana in search for better employment opportunities. However, the income generated from irrigation farming, due to the associated challenges is not enough to reduce the number of the youth who out-migrate annually by a significant proportion. This is evidenced by the statistics from the Ghana Statistical Service indicating a net out migration of 43 percent of the 15 to 19 age cohort who are basically the youth and future of the district (GSS, 2002). Obviously, the Tono scheme has had moderate effects on the youth's desire to out-migrate.

\section{Challenges of irrigation farming}

On the production side, the challenges facing project farmers is the poor supply of water to irrigation farmlands. While irrigation water is vital for crop production, as high as 43 percent of the project famers were dissatisfied with the supply of water to their farms. Farmers complained of irregular flow of water, and broken sub-canals. This puts farmers in situations where crops experience water stress due to lack of water thus affecting their yield and subse- quently their income.

Another factor which is crucial to the farmers is their inability to access credit for crop financing. Although famers are aware of loans provided by IFAD/ADB at 18 percent interest per annum, other elements associated with unpredictable outcomes puts farmers in a dilemma as to whether they can pay back loans collected or not. The farmers were hesitant to access credit to finance farm activities. They were, therefore, unable to purchase modern machinery, insecticides and higher yielding seeds and cater for storage.

Technical assistance from agricultural extension officers has tendered to be inadequate. More than one-third (i.e. 38.7 percent) of the project farmers do not have access to extension services at all. Against this background, farmers were faced with the problem of crop diseases, pest attacks and ignorance of modern farm practices. The absence of the needed assistance from technical officers had dire consequences on production and post-harvest practices. The inability of management to support farmers financially and materially at the right time contributed to the limited positive impact of the public irrigation scheme to farmers. This had to do with the weak operational capacity of the institutions in the form of logistics and delayed release of funds from government.

On the marketing side, one of the important factors that served as a challenge to irrigation farmers in the district especially project farmers was market limitation. While farmers recorded bumper harvest at the end of each farming season, getting ready market for their produce was a problem. Since the bulk of these produce are mostly vegetables thus perishable, farmers were compelled to sell their produce at 'give away prices' to avoid total loss. In such situations, farmers were not able to earn any significant profit from the huge capital investments put into their farms thus further entrenching them in the already existing poverty situation. The farmers were compelled to sell their perishable 
produce at very low prices to avoid losses since storage is not possible.

There is a fierce competition from irrigation farmers in neighboring Burkina Faso cultivating along the White Volta River basin. The same or similar crops compete for market from the same target group alongside vendors from urban centres in the South. The main reason that has led to a decline in the number of youth engaging in tomato cultivation over the years is attributed to this phenomenon. Unlike the Tono famers, irrigation farmers in Burkina Faso use manure and other non-chemical substitutes in the production of their crops. The use of chemicals by the Tono irrigation farmers to force-ripe the tomatoes results the reduction of the commercial quality to the advantage of imports (IFPRI, 2010; IFPRI, 2011). The Pwalugu Tomato Factory which was also to serve as a boost to tomato production in the irrigation areas in the region sadly operates far below its established capacity due to finance and operational mismanagement problems.

Clearly, the country's efforts aimed at promoting self-sufficiency in food production through irrigated agriculture amongst other strategies needs to be reviewed. What has become of the agro-industrial investments? If the farmers cannot store and market the perishable produce, what assistance can ICOUR and the other Government institutions give? Is it not possible to purchase, store/process and market these produce internationally? What role do the Ghanaian food canneries play in this direction? How about placing an embargo or increasing the taxes of imported food that can be produced in Ghana? The inability to find answers to these questions limits and in fact weakens the development of agriculture and should serve as a wake-up call to developers associated with the Tono irrigation scheme.

\section{Poverty reduction}

Irrigation Entrepreneurship

Irrigation farmers in Ghana are market-oriented by virtue of the nature of crops they cultivate which are tradable. In fact, they consume a smaller share of what is produced leaving the rest for sale. The processes of cultivation adopted are, nevertheless farmer driven. This ongoing type of endogenous irrigation development provides a strong backing that the way forward in the district and other districts with similar situations is for government to formulate policies that facilitate poor farmers becoming irrigation entrepreneurs. This is to enable farmers to respond to challenges posed by volatile market conditions and climate change. It will make them their own security seekers and enterprising in market search and marketing. Government can support the focus on entrepreneurship by enhancing the reliability of both input supply (i.e production) and demand sides (i.e. marketing) of the farmer's operations. These entrepreneurial skills can be transferred to irrigation farmers through the efforts of wellequipped extension officers in the district and nationwide.

\section{Adopting of Appropriate Technology}

The farmers' choice of crop varieties is somewhat influenced by access to seeds, growing techniques, available markets, potential yields, prices, and risk. At Tono irrigation scheme many farmers farmer are apparently reluctant to purchase improved seed varieties (Orchard and Suglo, 1999). They extract from the tomatoes they produce, wash and sow and plant the seedlings culminating in seed recycling. Purchased inputs (seed, fertilizer, pesticide and fungicide) increase the production costs to the farmers at the Tono irrigation scheme. Land husbandry practices at the irrigation site especially in tomato sector vary by farmer. Poor practices and poor land husbandry are common to tomato farmers. In the case of nursery management, the farmers broadcast the seeds and the seedlings eventually compete for nutrients and light. Fungal and viral infestations in the nursery beds which include tomato yellow leaf curl virus affect production. Continuous tomato cropping instead of rotated land use for tomato production increases the prevalence of soil borne pathogens. Weed control is another pro- 
70

blem because labour is manual. The farmers mix combinations of insecticides and fungicides and apply on their farms without knowing their specific names and purposes. It is suggested that Agricultural Extension Services Division and ICOUR organize training for irrigation farmers on land husbandry, weed and disease control practices.

\section{Farmer-Factory Collaboration}

One of the biggest challenges irrigation farmers face in the district is the limited local market. The existence of the Pwalugu Tomato factory ought to be a perfect avenue to solve the problem of ready market for tomato farmers of the Tono Irrigation scheme and in the district. Its poor performance is due to inadequate finance and mismanagement of state resources. Government's partnership with Pwalugu Tomato factory to resource its operation through procurement of additional finance and large storage facilities is one option. This will enhance the factory's ability to purchase and store large quantities of tomatoes produced by project farmers. To ensure that farmers produce the right quality of tomatoes for the factory, the factory management can assist farmers through technical know-how, detailed monitoring of farming practices, and provision of quality and appropriate seedlings. Establishing a close supplier-buyer relationship between Tono tomato farmers and the factory will certainly be beneficial to both parties.

\section{Cultivating in Phases}

A strategy to ensure market for vegetables is for the farmers to nurse tomato and pepper seedlings in phases. The reason why farmers do not get good market for their produce is because the bulk of the farmers nurse the tomato and pepper seedlings at the same time (November) and harvest at the same time (April). To reduce the risk of glut, farmers can crop in phases. That is, while a batch of farmers are encouraged to nurse say in November, a second group is encouraged to nurse in December and the third group in January. This will ensure that farmers harvest at different times reducing over production and ensuring the availability of vegetables all year round.

\section{Function of ICOUR}

ICOUR was set up as a limited liability company to operate on its own without direct government intervention in terms of its technical and resource management. This has not been the case particularly when it is unable to generate enough resources for the maintenance and repair of the irrigation infrastructure. The company is still being sub-vented by the government to run its capital and current expenditure.

If a new approach is to be successful, government needs to direct efforts towards training existing staff, attracting new talent through forward-thinking curricula as well as building the capacity of all stakeholders (including the irrigation bureaucracy). The initiatives should include a review of engineering courses in universities, conducting in-depth training workshops for farmers and irrigation officials. Subcontracting the operations of the various aspects of the project to viable private companies is quite possible with the government then weaning itself off in the medium to long-term.

\section{CONCLUSION}

Poverty is a global challenge to development and nationhood. Various strategic poverty reduction programmes have been initiated and implemented by the Government of Ghana to curtail poverty. Among these initiatives is the enhancement of irrigated agriculture through the creation of large scale public irrigation schemes. Irrigated agriculture offers opportunities for livelihoods security and poverty reduction. It is of particular significance in Northern Ghana where the climatic conditions do not allow for an all-year-round agricultural production. Tono irrigation scheme in the KassenaNankana District is one of such strategic initiatives towards poverty reduction and livelihood enhancement in Northern Ghana. Tono irrigated scheme has created a platform for employment and high agricultural production. Amidst the modest gains that have been made towards poverty reduction through the scheme, 
Irrigated agriculture and poverty reduction in Kassena Nankani district...

more efforts need to be exerted. There are challenges varying from limited market access to the fierce competition from nearby Bourkinabe irrigation famers, through inadequate technical assistance from agricultural extension officers, and poor access to credit for crop financing to poor supply of irrigation water and poor marketing.

Addressing the challenges squarely has the potential of directly contributing to the attainment of poverty reduction in the KassenaNakana District in particular and Ghana in general. The attendant actions will not only increase the farmers' production and incomes, but also enhance their opportunities to diversify their income base, and to reduce their vulnerability to the seasonality of agricultural production. A more responsive institutional arrangement inclusive of all the pertinent stakeholders is recommended to ensure the effective management and utilisation of the irrigation infrastructure; the efficient delivery of farm inputs to farmers; farmer centred capacity building training, the establishment of agro-industry processing linkages, market search and promotion.

\section{REFERENCES}

Aryeetey, E and McKay, A. (2004). Operationalizing Pro-Poor Growth: Ghana Case Study. Department for International Development and World Bank, London, UK.

Anambama, Y. D. (2008). Irrigation-led Strategy for Poverty Reduction in Northern Ghana: Large Scale Versus Small Scale Irrigation, Gauging the Evidence, Institute of Social Studies, The Hague.

Asare, B. (2002). Local involvement in rural development: The Tono Irrigation Scheme in Ghana. Development Practice. 12:218-223.

Donkoh S. A., Ayambila, S. and Abdulai, S. (2013). Technical Efficiency of Rice Production at the Tono Irrigation Scheme in Northern Ghana. Am. J. Exp. Agric. 3(1):25-42.
Science Domain international, www.sciencedomain.org. (Accessed 30 ${ }^{\text {th }}$ March, 2011).

Booth, A. and Mosley, P. (ed.) (2003). The New Poverty Strategies, What Have They Achieved, What Have They Learnt. New York: PALGRAVE MACMILLAN, Hound mills, Basingstoke, Hampshire, RG21 GXS and 175 Fifth Avenue, New York, N.Y. 10010 .

FAO (1999). Poverty Reduction and Irrigated Agriculture, International Programme for Technology and Research in Irrigation and Drainage (IPTRID). Rome, Food and Agricultural Organization of the United Nations.

FAO (2007). Dams and Agriculture In Africa, Water Development and Management Unit (NRLW), Land and Water Division (NRL), Food and Agriculture Organization of the United (Accessed 12/11/2010)

GLSS (2000). Ghana living Standard Survey Report, 2000, Ghana Statistical Service, Accra.

GNA (2010). Ghana Spends $\$ 450 \mathrm{~m}$ on Rice Importation Annually, www.ghanaweb.com Last updated 09/08/2010. (Accessed 30 March, 2011).

GoG (2010). Ghana's Demographic characteristics, www.ghanadistricts.com/districts. (Accessed on $26^{\text {th }}$ march, 2011).

GSS (2002). 2000 Ghana population and housing Census, Summary Report of Final Results, Accra, Ghana Statistical Services.

GSS (2008). 2003 Core Welfare Indicators Questionnaire (CWIQ) Survey: National and Regional Summary, Accra, Ghana Statistical Services, Ghana.

ICOUR (2007). Corperate Plan: 2006-2010. Navrongo, Ghana 
ICOUR (2010). ICOUR Corporate Plan: 20092014, Navrongo, ICOUR, Navrongo, Ghana.

IFAD (2001). The Rural Poor Rural Poverty Report 2000/2001 Fact Sheet - The Rural Poor. Rome, Italy.

IFPRI (2010). The Case of Tomato in Ghana, Ghana Strategy Support Programme, GSSP Working Paper No 019, Accra

IFPRI (2011). Irrigation development in Ghana: Past Experiences, Emerging Opportunities and Future Directions, Ghana Strategy Support Programme, GSSP Working Paper No 027, Accra

IWMI (2007). Pro-poor Intervention Strategies in Irrigated Agriculture: Lessons from the Asian Experience, Sri Lanka, IWMI

KNED (Kassena-Nankana District Assembly) (2010). KNED Medium Term Development Plan: 2010-2013, Kassena-Nankana East District Assembly. Navrongo, Ghana.

NDPC (2009). The implementation of the Growth and Poverty Reduction Strategy
(GPRS - II) 2006 - 2009: Annual Progress Report, Accra, Ghana.

ODI and CEPA (2005). Economic Growth in Northern Ghana Revised Report for DfID, Accra, Ghana.

Orchard, J. E. and Suglo, K. J. (1999). Integrated food crops projects: Enhancing smallholder livelihoods through reducing cost and adding value to agricultural production. Final Technical. Report, June. U.K.: Natural Resource Institute and Ministry of Agriculture Ghana.

Salifu, J. D. (1998). Socio-Economic Impact of the Tono Irrigation Project in The KassenaNankani District. BA-Thesis, University of Ghana, Legon, Accra.

UNDP (2008). Human Development Report 2007/2008. Fighting Climate Change: $\mathrm{Hu}-$ man Solidarity in a Divided World, New York.

WFP (2009). Ghana Comprehensive Food Security and Vulnerability Analysis Assessment, United Nations Accra Office, Ghana. 